\title{
Teaching Legal English for Company Law: A Guide to Specialism and ELP Teaching Practices and Reference Books
}

\author{
María José Álvarez Faedo \\ University of Oviedo \\ mjfaedo@uniovi.es
}

\begin{abstract}
This article discusses one of the less mainstream areas of ESP teaching, that of legal English for students of company law. The author begins by analysing the approach used by subject-domain specialists themselves and the current criticism regarding the conservative textbook approach which continues to dominate teaching theory in this area. To this effect, she presents the results of a study carried out from October 2014 to March 2015 regarding subject-domain textbooks most used in Law Schools in Australia, Britain, Canada and the USA. The paper then addresses the question of teaching legal English to students of company law. After a brief outline of the three main theories underlying language teaching -behaviourist, cognitive and communicative- the author provides a critical guide to the main course books available to teachers in this rarefied area of specialised language learning, listing the types of exercises proposed, and evoking their overall strengths and weaknesses. To conclude, she suggests means of supplementing course book material.
\end{abstract}

Keywords: Company Law, ESP, Legal English, reference books

The main concerns of ESP have always been, and remain, with needs analysis, text analysis, and preparing

learners to communicate effectively in the tasks prescribed by their study or work situation.

(Dudley-Evans \& St John, 1998: 1) 
To avoid venturing into "the deep waters of the definition of company law" (Bradley and Freedman, 1990: 398), as a non-specialist of the domain, we propose to adopt the definition offered by the online WebFinance, Inc. Business Dictionary (2015), according to which company law is the "legislation under which the formation, registration or incorporation, governance, and dissolution of a firm is administered and controlled", 2 and, as such, covers two main fields: corporate governance and corporate finance. The former, in the UK, concerns the constitutional separation of powers, shareholders' rights, employees' rights, directors' duties and corporate litigation. The latter deals with debt finance, equity finance, market regulation, accounts and auditing and mergers and acquisitions. However, the focus of this article is not on the subject matter from a legal or economic perspective, but from that of what may be considered a contributory science, i.e., the teaching of English for Legal Purposes (henceforth ELP).

In his article entitled "Using theory to study Law: A Company Law Perspective" (1999: 198), Brian R. Cheffins, professor of law at the University of Cambridge, evokes the role of contributory sciences and interdiscplinarity in the study of law and defines theoretical scholarship "as the study of law from the "outside", which "implies the use of intellectual disciplines, external to law, to carry out research on its economic, social or political implications. [T]ypically, the techniques and approaches are in fact borrowed from the social sciences and the humanities".

With this perspective in mind, this article approaches the teaching of company law within the legal English framework from an interdisciplinary and pedagogical point of view. In a first part, we provide a brief overview of the current state of research on the teaching of company law as a specialism, followed by a discussion on new trends in the field. In a second part, the focus shifts to ELP and we discuss several references on teaching legal English for company law.

\section{The classic textbook approach to teaching company law}

Before discussing concerns related to teaching the specialised language and discourse of English for company law, we propose to examine dominant trends regarding the teaching of the specialism itself.

In her article entitled "The story of a Phoenix, a Chef and some Raptors: Piecing together the Company Law Jigsaw" (2010: 4), Marion Oswald, a solicitor and senior lecturer in law, presents a survey related to the teaching of company law conducted in 1989 to "gather information about company law teaching practices across a range of institutions", the results of which were published in 1990 in an article entitled "Company law on degree courses: survey report", authored Ian Snaith, an Emeritus Law Professor at the University of Leicester. Oswald (2010: 4) points out that Snaith's findings indicate an essentially conservative text-book based approach to teaching company law with a focus on 'black-letter' ${ }^{4}$ law dominating. Law classes typically adopted the following approach: 
A course consisting of weekly lectures and fortnightly tutorials assessed by examination only is the paradigm. The recommendation of a textbook and a casebook is usual and the provision of materials specially prepared by the institution is rare. Course content tends to follow the order and substance of textbooks (Snaith, 1990: 182).

According to Bradley and Freedman such a text-book based approach “... fails to prepare the student for anything other than the examination (or maybe a nervous breakdown)" (1990: 399).

Snaith offered three possibilities that could serve as "conceptual frameworks" to be used "for the selection and organisation of material":

[F]irst, an analysis based on the different interests of various groups, secondly a focus on the way company law affects small businesses and multinationals and thirdly an analysis based on view(s) of society. Snaith acknowledged that none of the possibilities offered "a complete solution" but suggested that further debate could assist company law teachers in providing stimulating courses that developed students' skills (Oswald, 2010: 4-5).

Oswald reports that improving the methodology employed to teach Company Law remains a subject of concern and that researchers and teachers agree in rejecting "a purely doctrinal black-letter approach" (Oswald, 2010: 5) in favour of a broader interdisciplinary outlook. However, they also agree that the need for a broader outlook is essential and that "company law cannot be segmented, even at the start...one needs to start with some idea of the completed picture". To achieve this, "a narrative approach is essential, through lectures and seminars or through books" (Bradley and Freedman, 1990: 339). Oswald offers a brief review of different academic texts ${ }^{5}$ on company law which attempt to offer a new approach that explores the underlying social, political and economic background to the corporate form:

rather than following a format dictated by a core textbook (perhaps more readily assessed by a final examination), it was considered more beneficial to devise a teaching and assessment model that combined an exploration of the law with a narrative, law-in-context, skills-based and experiential approach, and which was supported by a specially prepared course handbook (2010: 6-7).

She concludes by praising the success achieved in designing company law courses in this perspective, arguing that a course "which develops a broad and contextual understanding of the law, and which encourages in students a flexibility and adaptability of approach, may play a small part in preparing students for the challenging legal, economic and social decisions that they will face in the future" (Oswald, 2010: 11). 


\section{New trends in the teaching of company law}

In view of the international context of the teaching of company law, it is worth pointing out that differences of approach exist, especially between the UK and the USA. In this respect, Brian R. Cheffins points out that "the controversy which has arisen in the United States concerning the relationship between law and theory has, as of yet, attracted little attention in Britain" (1999: 197). He nevertheless goes on to suggest that "the emergence of theoretical company law scholarship has not been restricted to any one country. Australian, British and Canadian academics have all carried out important interdisciplinary work" (1999: 209).

Given that the results of the survey discussed above were published 25 years ago, and Oswald's opinion that the didactic approach to this subject has begun to change, we decided to carry out a study to gain further insight into the approaches used by company law teachers by analysing the type of academic texts and methodology in use in Law schools in the United Kingdom, the USA, Australia and Canada by law lecturers teaching company law.

The study was carried out from October 2014 to March 2015 and concerned the type of academic references and methodology used in law schools in the United Kingdom, the USA, Australia and Canada by law lecturers teaching company law in English over the last fifteen years. Our findings reveal that the most frequently used academic texts on company law are the following (presented in chronological order):

Clive M. Schmithoff and James H. Thompson's (eds.). (1992). Palmer's Company Law (London: Stevens): a major reference book. For over 100 years Palmer has provided students and professionals with essential commentary on company law, as well as with revised and up-to-date narrative and source materials.

Simon Goulding. 1998. Principles of Company Law (London: Routledge Cavendish): a volume that offers the reader a brief explanation of each issue in company law, a summary of the rules as well as a number of important cases which are analysed and discussed.

Robert Pennington. 2001. Pennington's Company Law. (Kiddlinton: Butterworths): considered a classic text and currently in its third edition, this volume is one of the leading works on the subject, with a strong focus on cases and their impact on the existing companies Act.

J. Boyle and Richard Sykes (eds.). 2004. Gore-Browne on Companies (Bristol: Jordans, Ltd.): originally published in 1873 , the $44^{\text {th }}$ edition of the classic work on company law by Sir Francis Gore-Browne is revised by the editors to take into account new legislation with commentary on issues arising from the Companies Act 2006.

Paul Davies and Sarah Worthington. 2012. Gower \& Davies: Principles of Modern Company Law. (London: Sweet \& Maxwell): a comprehensive text which offers a clear analysis of modern company law, in spite of a certain number of mistakes in relation to 
section numbers which still pervade the text in its third edition since the Companies Act 2006.

Brenda Hannigan. 2012. Company Law (Oxford: Oxford University Press): a full and thorough academic text and a good source of alternative reading to Gower and Davies. It brings clarity and offers in-depth analysis to a company law landscape that was considerably altered by the 2006 ground-breaking Companies Act.

Len Sealy and Sarah Worthington. 2013. Cases and Materials on Company Law (Oxford: Oxford University Press): a well-researched account of the law, which also offers students extracts from the key cases and materials.

Alan Dignam and John Lowry. 2014. Company Law (Oxford: Oxford University Press): a reliable guide for students of law at all levels. The book offers a good introduction and its concise texts explain the intellectual challenges each area of the law presents for students.

Derek French, Stephen Mayson and Christopher Ryan. 2015. Company Law (Oxford: Oxford University Press): sometimes described as dense, full, factual but boring, its accompanying Online Resource Centre, which provides quarterly updates, is certainly a plus. Besides, it also includes the 2015 Acts, Regulations and Deregulation Act.

Alongside these major reference books that have been and are still used in their updated versions, other new references offering new approaches to company law have been now emerged and, apparently, welcomed in spite of the traditional teaching practices and methods adopted by most company law teachers, a phenomenon that Cheffins (1999: 213-214) comments:

[There are] a variety of possible explanations for the absence of a hostile reaction to the emergence of new approaches in Company Law. First, indifference and ignorance might have played a role. Lawyers and judges who choose not to pay attention to the academic literature are unlikely to react in an adverse manner to new trends. A second possible answer is that practitioners who do follow academic writing are unconcerned by the change in approach because a substantial amount of doctrinal scholarship is still being produced. In Britain, for example, both academics and practising lawyers continue to contribute to a rich body of company law literature devoted to the analysis of cases and the description of statutory measures. Third, those members of the legal profession who are familiar with theoretical company-law literature may be favourably impressed with the work which is being done. There is in fact some anecdotal evidence which supports this proposition and it probably should not be surprising that this is so.

In the last fifteen years, lecturers teaching company law have adopted a broader perspective and incorporated other means of teaching company law ${ }^{6}$ rather than through the classic "textbook" approach, as the following examples show:

- Taking into account that company law is a subject that draws on both statutory and case material, and that statutory material is complex, students are advised to 
search for additional material on their own after reading the descriptions in the textbooks prescribed. The idea is that students should become familiar with the structure and drafting of company legislation to gain better understanding of some of the topics covered in the course.

- The use of tutorial sheets, in addition to the relevant case material, including, for instance, relevant case reports from Paul L. Davies' Gower and Davies' Principles of Modern Company Law, and Hicks and Goo's Cases and Materials $n$ Company Law. Students are also encouraged to consult full reports of cases. Since the facts of the cases are frequently complex, diagrams of company structures and transaction illustrations can facilitate students' understanding of the facts of the cases.

- Tutorials are also concerned with making students consider and discuss issues such as what interests are relevant in the regulation of companies and whether the present structure of company law is adequately designed to meet those interests.

- To add an element of "realism" to the course, some lecturers allocate a specific listed company (i.e., one whose shares are traded on the London Stock Exchange) to each tutorial group which it must subsequently monitor. The companies selected all have websites which enable students to supplement the information provided by lecturers. They are required to collect information on "their" company by visiting http://www.ft.com/markets/uk and doing a search from there via "markets and funds data" for the evolution of share prices, etc. Students are also encouraged to check the business pages of other newspapers for comments regarding "their" company, it being up to them to assess the reliability of the source (specialized journal, quality newspaper, official source, etc.). They are also invited to embark on monitored web quests to search for information that may help them solve a problem regarding a particular case.

\section{Teaching legal English to students of company law}

After the brief overview of teaching trends in company law by subject-domain specialists, we now focus on the teaching of English in relation to this area of studies.

The change in teaching approaches to company law at law faculties -i.e., the introduction of new elements in addition to the classic academic text- in the last fifteen years is an interesting evolution in that it is the opposite to the evolution in English for Specific Purposes (ESP). In the late 1990s there was still a scarcity of what might be considered "textbooks" in ESP, leading Dudley-Evans and St John to conclude that ESP practitioners had often not only to plan the course they taught, but also to create and provide the materials for it: "[For ESP practitioners] it is rarely possible to use a particular textbook without the need for supplementary material, and sometimes no really suitable published material exists for certain of the identified needs" (1998: 14). The scarcity of published material is a problem ESP teachers have been facing, to a 
greater or lesser degree according to the subject-domain, since the inception of ESP - a very different situation to that of speciality lecturers, who usually recommend their students buy a textbook and are seldom called upon to create or otherwise prepare "customised" materials for them.

The absence of easily available pedagogic resources naturally led to the role of ESP teachers as "providers of material [a task which] involves choosing suitable published material, adapting material when published material is not suitable, or even writing material when nothing suitable exists" (Dudley-Evans \& St John, 1998: 15). As such, the ESP teacher's role as a provider of teaching materials may be summed up in terms of three variables:

a) Choosing suitable published material;

b) Adapting material when published material is not entirely suitable;

c) Creating material when nothing suitable exists.

The first variable involving "choosing suitable published material" for teaching legal English for students of company law, led us to analyse existing didactic materials available in English for company law. We retained six recent publications which we esteemed worthy of interest:

Ian Mackenzie. 2007. Professional English in Use: Finance. Cambridge: CUP.

Gillian D. Brown \& Sally Rice. 2007. Professional English in Use: Law. Cambridge: CUP.

Jeremy Day with Amy Krois-Lindner and Matt Firth. 2008. Introduction to International Legal English. Cambridge: CUP.

Marcella Chartrand, Catherine Millar and Edward Wiltshire. 2009 (1997). English for Contract and Company Law. Andover: Sweet \& Maxwell.

William R. McKay's and Helen E. Charlton. 2011 (2005). Legal English: How to Understand and Master the Language of the Law. Harlow: Pearson / Longman.

Amy Krois-Lindner. 2011. International Legal English. Cambridge: CUP.

An important parameter to be borne in mind in this context is the profile of the target public both with regard to the language level and specialised knowledge of the subject-domain. As regards the language level, the students concerned were a group of 25 second-year law students at the University of Oviedo whose level of English was rated at a minimum of B1 (which is often the case in Law Schools all over Europe). Concerning specialised knowledge, the ELP teacher is confronted with a major handicap in this particular context in that these students do not study company law before the second semester of their second year whereas their ELP course takes place in the first semester. As such they have little or no knowledge of company law and their legal English course is, in fact, their very first exposure to their future area of 
specialisation. In view of the above elements, the ELP teacher needs to factor in a relatively low level of language competence and subject-domain knowledge when designing the course.

What of learner profiles with regard to expectations? On the first day of class students are always asked about their expectations and how they would like to learn the specialised language and discourse of company law. Students tend to show a preference for a textbook approach, particularly those students who come via exchange agreements with their universities (Erasmus, for example). It often happens that these students have already taken a legal English course at their own universities based on a textbook approach and expect, as such, to dispose of a "textbook" of legal English and be examined on the basis of its content. Spanish students also showed a preference for disposing of a prescribed book on the grounds that other options would turn out to be more expensive and complicated for them. It is interesting to note that these first impressions were to change completely by the end of the course.

In this context of pedagogic expectations, we also need to take into account such theories of learning, as the Behaviourist Theory, the Cognitive Theory and the Communicative Approach. If the first "portrayed the leaner as a passive receiver of information", the second "takes the learner to be an active processor of information" (Hutchinson \& Waters, 1987: 43), whereas the third, first postulated by Dell Hymes (1972), presents teacher and learner as participants in the negotiation of meaning and communication.

The Behaviourist Theory was postulated by Pavlov, in the Soviet Union, and promoted by Skinner in the United States. It regards learning as a "mechanical process of habit formation and proceeds by means of the frequent reinforcement of a stimulusresponse sequence" (Hutchinson \& Waters, 1987: 40). This led to the assumption that second language learning should imply a reflection and imitation of the perception speakers may have of the process of learning their mother tongues. Accordingly, translating was tabooed since the sequence learners were expected to conform to when learning new elements was that of 'hear, speak, read and write'. It was also believed that effective learning was achieved through frequent repetition and the immediate correction of all errors. For behaviourists, many detractors believed, learners were only instruments to be manipulated by their teachers.

As regards the Cognitive Theory, Hutchinson (1987: 43) explains that "the basic teaching technique associated with a cognitive theory of language learning is the problem-solving task". The cognitive theory of learning regards second language acquisition as a thinking process which is conscious and reasoned, and in which learning strategies are consciously used. Learning strategies are defined as ways of processing information to improve comprehension, learning or retention of information, in contrast to the behaviourist approach to language learning which considers language learning an unconscious and automatic process. The cognitive approach insisted on the importance of meaningful practice and, as such, believed in inductive methods, i.e., rules were elicited after exposure to examples. 
Communicativists, on the other hand, confer more importance to the semantic content of language learning. In other words, students do not learn the grammatical form before meaning but through it. Therefore, "learning activities are selected according to how well they engage the learner in meaningful and authentic language use (rather than merely mechanical practice of language patterns)" (Richards \& Rogers, 2014 [1986]: 90). ${ }^{7}$ If cognitivists postulate the problem-solving task as their basic teaching technique, communicativists claim that theirs is a task-based approach.

Accordingly, the communicative method uses conversation, reading, listening comprehension and writing in order to define its objectives precisely. To that aim, this approach resorts to all means of communication and media, such as newspapers, television, cinema, radio, computers, the Internet, etc., which are commonly used when people seek and exchange information. As such, the textbook is no longer the supreme means of language learning in the classroom.

In the specific context of English for company law, there are a number of publications which focus on this area of ELP. In the context of this study, and with a view to guiding present and future teachers in the relatively unexplored area of legal English for company law, we undertook to analyse these publications to determine which approach -behaviourist, cognitive or communicative- the authors privileged judging from the exercises proposed, and consider which would be most suitable in the context of teaching legal English for company law in a dynamic interdisciplinary perspective. ${ }^{8}$

\section{- Ian Mackenzie. 2007 (2006). Professional English in Use: Finance, Cambridge, CUP.}

This author devotes two chapters out of fifty (chapters 5 to 6 of the section "Accounting") to "Company Law", in a book intended for the teaching of financial English to students.

Table 1. Chapters on company law in Mackenzie's Professional English in Use: Finance.

\begin{tabular}{ccl}
\hline Unit 5 & $\begin{array}{c}\text { Company Law } \\
\text { p. } 16\end{array}$ & $\begin{array}{l}\text { A. Partnerships } \\
\text { B. Limited Liability } \\
\end{array}$ \\
& & C. Founding Companies \\
\hline Unit 6 & $\begin{array}{c}\text { Company Law } \\
\text { p. } 18\end{array}$ & $\begin{array}{l}\text { A. Private and public companies } \\
\text { B. AGMs }\end{array}$ \\
\hline
\end{tabular}

Mackenzie's target students are "intermediate and upper-intermediate learners of business English", and the objective defined is that of improving learners' financial vocabulary (Mackenzie, 2007 [2006]: 6). Each unit covers two pages, the page on the left presenting a text defining each of the topics to be dealt with, while the page on the right contains two or three exercises which are the practical counterpart for the theory displayed on the page opposite. 
Table 2. Typology and frequency of exercises in Mackenzie's Professional English in Use: Finance.

\begin{tabular}{|c|c|}
\hline Exercises proposed & Frequency \\
\hline Match the two parts of the sentence. & 1 \\
\hline $\begin{array}{l}\text { Find words from A and B opposite with the following } \\
\text { meanings }\end{array}$ & 1 \\
\hline $\begin{array}{l}\text { Make word combinations from } \mathrm{C} \text { opposite using words } \\
\text { from box. Then use appropriate word combinations to } \\
\text { answer the questions below. }\end{array}$ & 1 \\
\hline $\begin{array}{l}\text { Complete the document. Look at A opposite to help } \\
\text { you. }\end{array}$ & 1 \\
\hline $\begin{array}{l}\text { Complete the table with words from A and B opposite } \\
\text { and related forms. }\end{array}$ & 1 \\
\hline Are the following statements true or false? & 1 \\
\hline $\begin{array}{l}\text { Over to you: questions to reflect on re-using elements } \\
\text { learnt in each unit, relating it to everyday activities. }\end{array}$ & 2 \\
\hline
\end{tabular}

This method may be considered as being more influenced by the communicative approach, given the attempt to contextualise what students have learnt in relation to their everyday activities and the absence of any kind of emphasis on repetition. In spite of a certain number of advantages, the book presents a major drawback in that all the units present exactly the same structure, which tends towards a certain degree of monotony. Additionally, it includes no audio-visual material. Consequently, this book would lend itself better to selective use of certain exercises.

\section{- Gillian D. Brown and Sally Rice. Professional English in Use: Law, Cambridge, CUP, 2007.}

These authors devote ten chapters out of forty-five (chapters 19 to 28, i.e., nearly one fourth of the book) to the section "Law in Practice", where they use examples from diverse aspects of company law.

Table 3. Chapters on company law in Brown and Rice's Professional English in Use: Law

\begin{tabular}{lcl}
\hline Unit & Business & A. Sole trader \\
19 & Organisations & B. Partnerships Liability \\
& p. 44 & C. Limited Companies \\
\hline Unit & Formation of a & A. Incorporation \\
20 & Company & B. Memorandum and Articles \\
& p. 46 & of Association \\
\hline
\end{tabular}




\begin{tabular}{|c|c|c|}
\hline $\begin{array}{l}\text { Unit } \\
21\end{array}$ & $\begin{array}{l}\text { Raising capital } \\
\text { by share sale } \\
\text { p. } 48\end{array}$ & $\begin{array}{l}\text { A. Share capital } \\
\text { B. Share value } \\
\text { C. Rights attaching to shares }\end{array}$ \\
\hline $\begin{array}{l}\text { Unit } \\
22\end{array}$ & $\begin{array}{l}\text { Debt financing: } \\
\text { secured lending } \\
\text { p. } 50\end{array}$ & $\begin{array}{l}\text { A. Granting security } \\
\text { B. The terms of a charge }\end{array}$ \\
\hline $\begin{array}{l}\text { Unit } \\
23\end{array}$ & $\begin{array}{l}\text { Company } \\
\text { directors and } \\
\text { company } \\
\text { secretaries } \\
\text { p. } 52 \\
\end{array}$ & $\begin{array}{l}\text { A. Qualifications and duties of } \\
\text { a company director } \\
\text { B. Qualifications and duties of } \\
\text { a company secretary }\end{array}$ \\
\hline $\begin{array}{l}\text { Unit } \\
24\end{array}$ & $\begin{array}{l}\text { Insolvency and } \\
\text { winding up } \\
\text { p. } 54\end{array}$ & $\begin{array}{l}\text { A. Insolvency } \\
\text { B. Insolvency scenarios }\end{array}$ \\
\hline $\begin{array}{l}\text { Unit } \\
25\end{array}$ & $\begin{array}{l}\text { Alternative } \\
\text { dispute } \\
\text { resolution } \\
\text { p. } 56\end{array}$ & $\begin{array}{l}\text { A. Alternative dispute } \\
\text { resolution } \\
\text { B. ADR procedures }\end{array}$ \\
\hline $\begin{array}{l}\text { Unit } \\
26\end{array}$ & $\begin{array}{l}\text { Corporation tax } \\
\text { p. } 58\end{array}$ & $\begin{array}{l}\text { A. Incorporation } \\
\text { B. Memorandum and Articles } \\
\text { of Association }\end{array}$ \\
\hline $\begin{array}{l}\text { Unit } \\
27\end{array}$ & $\begin{array}{l}\text { Mergers and } \\
\text { acquisitions } \\
\text { p. } 60\end{array}$ & $\begin{array}{l}\text { A. Mergers and acquisitions } \\
\text { B. Dealing disclosure } \\
\text { requirements }\end{array}$ \\
\hline $\begin{array}{l}\text { Unit } \\
28\end{array}$ & $\begin{array}{l}\text { Anti- } \\
\text { competitive } \\
\text { behaviour } \\
\text { p. } 62\end{array}$ & $\begin{array}{l}\text { A. Competitive law } \\
\text { B. Competition inquiry } \\
\text { C. Information gathering, } \\
\text { hearings, and remedies }\end{array}$ \\
\hline
\end{tabular}

According to the authors, the target students are "learners who have reached an upper-intermediate or advanced level of English", and may be "lawyers or litigators, paralegals or legal researchers or trainee lawyers" (2007: 6).

Once again, each unit covers two pages, the page on the left presenting a text related to a specific topic, while the page on the right contains two or three exercises which are the practical counterpart for the theory displayed in the page opposite.

Table 4. Typology and frequency of exercises in Brown and Rice's Professional English in Use: Law.

\begin{tabular}{lc}
\hline Exercises proposed & Frequency \\
\hline Matching sentence segments. & 3 \\
Replacing words and phrases underlined with alternative & 4 \\
words and phrases from A and B opposite. & \\
\hline
\end{tabular}




\begin{tabular}{|c|c|}
\hline Exercises proposed & Frequency \\
\hline $\begin{array}{l}\text { Making word combinations from } \mathrm{C} \text { opposite using words } \\
\text { from box. Then using appropriate word combinations to } \\
\text { answer the questions below. }\end{array}$ & 2 \\
\hline $\begin{array}{l}\text { X's client has sent an e-mail asking about shelf } \\
\text { companies. Complete X's reply. Look at A opposite to } \\
\text { help you. }\end{array}$ & 6 \\
\hline $\begin{array}{l}\text { X shows his client a sample memorandum. Replace } \\
\text { underlined words and phrases with appropriate legal } \\
\text { terms from A and B opposite. }\end{array}$ & 1 \\
\hline Completing definitions. Look at A opposite to help you. & 1 \\
\hline $\begin{array}{l}\text { Complete this extract with words from the box. Look at } \\
\text { A opposite to help you. }\end{array}$ & 3 \\
\hline $\begin{array}{l}\text { Complete the table with words from A and B opposite } \\
\text { and related forms. }\end{array}$ & 3 \\
\hline $\begin{array}{l}\text { Find answers to Y below. Look at A opposite to help } \\
\text { you. }\end{array}$ & 3 \\
\hline $\begin{array}{l}\text { Choose the correct word in brackets to complete the } \\
\text { sentence. Look at A opposite to help you. }\end{array}$ & 2 \\
\hline True or false statements & 1 \\
\hline $\begin{array}{l}\text { Over to you: questions to reflect on re-using elements } \\
\text { learnt in each unit and relating them to everyday } \\
\text { activities. }\end{array}$ & 1 \\
\hline $\begin{array}{l}\text { Over to you: same as above, but with supporting web } \\
\text { page. }\end{array}$ & 9 \\
\hline
\end{tabular}

This book tends to derive from the communicative approach, given the attempt to contextualise what students have learnt in relation to their everyday activities and the absence of emphasis on repetition. Nevertheless, it is worth pointing out that, since both this book and the previous one belong to the same series, it is not surprising that they offer a similar approach. As in the previous case, students are left with a sense of repetition given that all units have the same structure. Additionally, the book includes no audio-visual material. As such, the book is best used on the basis of selective use of exercises in combination with other materials.

\section{Amy Krois-Lindner and Matt Firth. 2008. Introduction to International Legal English, Cambridge, CUP.}

These authors devote one unit out of nine (unit 5) to "Company Law", in which they use examples from various aspects of this branch of the law to introduce students to legal English for company law. Two Audio CDs are included with the book. 
Table 5. Chapters on company law in Krois-Lindner and Firth's Introduction to International Legal English.

\begin{tabular}{|c|c|c|}
\hline Unit 5 & $\begin{array}{l}\text { Company Law } \\
\text { p. } 50\end{array}$ & $\begin{array}{l}\text { A. Company Law } \\
\text { B. Course in Company Law } \\
\text { C. Breach of Companies Act } 2006 \\
\text { 1. Lecture on Company Law } \\
\text { 2. Directors' meeting } \\
\text { Speaking } \\
\text { 1. Role-play: lawyer-client } \\
\text { interview } \\
\text { 2. Role-play: lawyer-client } \\
\text { negotiations } \\
\text { Key terms } 1 \\
\text { - Who does what in Company } \\
\quad \text { Law? } \\
\text { Key terms } 2 \\
\text { - Public relations } \\
\text { - Text analysis: reading a statute } \\
\text { Language use } \\
\text { - Discussing advantages and } \\
\text { disadvantages }\end{array}$ \\
\hline
\end{tabular}

The target students for this "intermediate level course" are "law students or newlyqualified lawyers who need to use English in their legal work or studies". 9 The unit covers 9 pages and it offers a more diversified range of activities -reading, listening, writing and speaking- in comparison with other books.

Table 6. Typology and frequency of exercises in Krois-Lindner and Firth's Introduction to International Legal English.

\begin{tabular}{l|c}
\hline Exercises proposed & Frequency \\
\hline Reading & 3 \\
Listening & 3 \\
Writing & 1 \\
Speaking & 2 \\
Use of English & 5 \\
Text analysis & 1 \\
\hline
\end{tabular}

Like the previous methods analysed, this method is also influenced by the communicative approach. The book seeks to "develop the four key skills of reading, writing, listening and speaking" and "is suitable for learners who may not have extensive knowledge of the law, taking them to the point where they can begin using the International Legal English course book and start preparation for the Cambridge 
ILEC examination". ${ }^{10}$ However, this book tends towards the cognitive approach as well since it also includes case studies.

Even if this book would appear to be more suitable for use in the classroom because of its combination of the cognitive and communicative approaches, given that its units though much longer than the ones in the previous two manuals and including audio material- still tend towards a certain degree of repetition, it would thus need to be supplemented by other supports to avoid monotony.

- Marcella Chartrand, Catherine Millar and Edward Wiltshire. 2009 (1997). English for Contract and Company Law, Andover, Sweet \& Maxwell.

The three authors of this book devote three chapters out of six -chapter 4 (The birth of a company), chapter 5 (The life of a company) and chapter 6 (The death of a company)to "English for Company Law". Their target students are "non-native English speakers with the English language skills necessary to carry out their legal studies effectively". ${ }^{11}$

Densely presented, each unit covers from twenty to thirty pages. The book's avowed aim is to "enable students to familiarise themselves with the documents they will come into contact with [through] a high level of specific legal content and practical materials, including cases, legislation, legal writings and examples". ${ }^{12}$

Table 7. Typology and frequency of exercises in Chartrand, Millar and Wiltshire's English for Contract and Company Law

\begin{tabular}{l|c}
\hline Exercises proposed & Frequency \\
\hline Reading comprehension & 12 \\
Reading (no comprehension exercises) & 12 \\
Discussion & 11 \\
Filling in the blanks & 17 \\
Crosswords & 3 \\
Matching exercises & 6 \\
Sentence completion & 4 \\
Note-taking & 1 \\
Summary writing & 3 \\
Rewriting & 3 \\
Writing & 5 \\
Completing grids & 2 \\
Text completion & 2 \\
Sentence expansion & 1 \\
Substitution & 1 \\
Vocabulary & 1 \\
Putting words in the right order & 1 \\
\hline
\end{tabular}

This method is influenced both by behaviourist and cognitive theories. In spite of the density of the units, the purpose of each exercise is not always apparent. Besides, despite the fact that the new edition includes a few crosswords, its lack of audio-visual 
material, the book format, and not-very-varied exercises are as out-dated as that of its previous edition.

- William R. McKay, Helen E. Charlton and Grant Barsoum. 2011 (2005). Legal English: How to Understand and Master the Language of the Law, Harlow, Pearson / Longman.

These three authors devote five chapters out of eleven -chapter 1 (Company formation), chapter 2 (Board meetings), chapter 3 (Shareholders meetings), chapter 4 (Boardroom battle!) and chapter 5 (Marketing agreements) - to part 1 "Business Law and Practice", in which they use examples from diverse aspects of company law. Their target students are "those aiming to study or presently studying law within an English language jurisdiction (whether for academic or vocational training purposes) [and] those presently involved in the legal or business domain whose work brings them into contact with legal practice" (McKay \& Charlton, 2005: 1). The book's aim is to enhance communication skills through a task-based methodology. Each unit covers from six to thirteen pages.

Table 8. Typology of exercises in McKay, Charlton and Barsoum's Legal English: How to Understand and Master the Language of the Law

\begin{tabular}{l|c}
\hline Exercises proposed & Frequency \\
\hline Reading comprehension & 6 \\
Drafting documentation & 7 \\
Letter writing & 1 \\
Role-play & 2 \\
Interviewing \& advising & 1 \\
Use of English & 5 \\
\hline
\end{tabular}

This method, as the previous ones, has also been influenced by the cognitive theory, given the presence of task-based exercises, although it also includes a number of roleplay exercises, so popular with behaviourists. Unfortunately, as in the previous case, the book retains the out-dated format of the first edition, which does not make it appealing to students.

\section{- Amy Krois-Lindner. 2011 (2006). International Legal English, Cambridge, CUP.}

This author devotes three units out of fifteen -unit 2 (Company Law: Company formation and management), unit 3 (Company Law: Capitalisation) and unit 4 (Company Law: Fundamental changes in a company) - to "Company Law", in which she uses examples from diverse aspects of this branch in an ELP perspective. Two audio CDs and a CD-ROM with practice tests are included with the book. The target students for this "upper-intermediate to advanced level course" are "learners who need 
to be able to use English in the legal profession", and "the course is intended for law students and practising lawyers alike" (2007 [2006]: 2). Each unit covers from 12 to 16 pages and proposes different exercises to practise reading, listening, writing and speaking skills, as well as general English usage.

Table 8. Typology of exercises in Krois-Lindner's International Legal English

\begin{tabular}{l|c}
\hline Exercises proposed & Frequency \\
\hline Reading & 11 \\
Listening & 6 \\
Writing & 3 \\
Speaking & 3 \\
Use of English & 36 \\
Research tasks, redirecting students to a specific web-site & 4 \\
\hline
\end{tabular}

The author clearly indicates that the book "has been written to prepare candidates for the New International Legal English Certificate (ILEC) examination developed by Cambridge ESOL and TransLegal" (Krois-Lindner, 2007 [2006]: 2). The presence of task-based exercises also indicates the influence of cognitive theories even though it also contains material characteristic of a communicative approach. Overall, this book provides a good pedagogic method, although the complexity of some of the exercises proposed could be a drawback to certain students. As such, it would benefit from being combined with other types of tasks and exercises.

To sum up this brief analysis of textbooks which present a certain interest to teachers of legal English for students in Company Law and the different theories they derive from, it is interesting to note that four out of the six books chosen have been designed in the task-based perspective of the cognitive theory, four of them in the communicative perspective and two present some influence from the behaviourist approach, thus clearly indicating the decline of behaviourist theories and the dominance of cognitive and communicative approaches.

\section{Conclusion: Suggested methodology for the teaching of the legal English for students of Company Law}

Contrary to Dudley-Evans and St John (1998: 15) who lamented the fact that ESP teachers had little published material to avail of, this study shows that, even in the context of such a specialised subject-domain as company law, there is a lot of the published material which is highly interesting. ${ }^{13}$

Nevertheless, given that the pedagogical perspective recommended in this article is based on an interactive multidisciplinary approach, it naturally follows that additional input in the direction of devising and analysing other ways of encouraging students' participation (problem-solving tasks, case studies and business simulations with original documents, etc.) is inevitable, notably with regard to presenting students with such real- 
life professional situations of communication as presentations, negotiations, telephoning, meetings, discussions, etc. In this respect, we would recommend two sources of pedagogic materials which derive from two different spheres: on the one hand, we strongly recommend reinforcing subject-domain knowledge through the use of sources relating to company law used by company law lecturers, professionals, specialised newspapers, etc.; on the other hand, another interesting and rich source of pedagogical material would also be the use of fiction relating to specialised fields, notably, in this age of visual literacy, films related to the world of companies and finance, such as The Social Network (2010), Wall Street 2. Money Never Sleeps (2010), Erin Brockovich (2000), A Civil Action (1998) or Wall Street (1987), to mention but a few. ${ }^{14}$ In ESP, as in law, there is no reason why lecturers should be restricted to a specific method; they should, on the contrary, feel free to combine existing academic texts and materials with non-academic ones and to create their own "customised" material.

\section{Notes}

1. This paper is the result of research funded by the University of Oviedo Innovation Project "Diseño de propuestas de configuración de asignaturas de Inglés y Francés como lenguas específicas y su articulación en las nuevas titulaciones de Grado partiendo de su situación actual como materias propias de las licenciaturas de Filología Francesa, Filología Hispánica, Medicina y Derecho. Referencias de partida: el EEES y Marco Europeo de referencia común para el aprendizaje de lenguas (MERC)" (Ref: PB-08-010).

2. A definition offered by the WebFinance, Inc. Business Dictionary (2015). In the United Kingdom, Company Law (or Corporate Law) regulates corporations formed under the Companies Act 2006. Being the primary legal entities to organise and run business, companies are also subject to the Insolvency Act 1986, the UK Corporate Governance Code, European Union Directives and court cases. See Kershaw (2009), Kraakman et al. (2009), Lowry and Dignam (2010), Sealy and Worthington (2010) and Topham (1978).

3. Black Letter Law, according to Duhaime's Law Dictionary, is "a principle of law so notorious and entrenched that it is commonly known and rarely disputed". (http://www.duhaime.org/LegalDictionary/B/BlackLetterLaw.aspx). Retrieved 2015/12/17.

4. "Hicks has argued for a company life-cycle approach by the use of an on-going case study, an approach put into practice in Cases and Materials. In Company Law in Context, Kershaw deploys a case-study following 'Bob's Electronics' as the business develops from sole trader, to private limited company to public limited company. Kershaw's aim 'is to place the student in the shoes of the business actor; to enable the student to empathise with the problems which a business person faces in setting up a business and the problems she is faced with as the company is formed and developed"' (Oswald, 2010: 5).

"Kingsford Smith advocated a law in context approach to the teaching of company law. She said that such an approach 'allows policy appraisal to co-exist with theory, doctrinal analysis with interdisciplinary insights. It invites a variety of approaches to teaching and learning... Importantly, it provides tools to ensure that students recognise that there are wider issues at stake than technical rules and norms of corporate practice.' She acknowledged that the use of problem-based learning should be combined with other techniques; an approach that 
overly focused on the transactional context of rules risked substituting 'another type of narrowness of vision for the much criticised over concentration on doctrine"” (p. 5).

"Copp supported the approach of Cheffins who argued that an interdisciplinary theoretical approach to the teaching of company law has a number of valuable benefits. Although a doctrinal or descriptive approach to teaching company law provided students with the ability to find necessary information, it ignored the social consequences of the law. Cheffins argued that a theoretical approach not only helped to provide 'the sort of liberal education which a university should be offering' but also enabled students to weigh up the benefits and burdens of the company law regime. Cheffins admitted that an approach purely focused on theory could be open to criticism: "there have been warnings that new approaches to company law should not operate wholly at the level of theory; academics instead should deal with concrete contemporary legal issues (e.g. the implications of the growing influence of institutional investors in public quoted companies)'"' (p. 5).

5. The core text-book Oswald chose was Mayson, French \& Ryan on Company Law, $26^{\text {th }}$ edn. 2009 (Oxford: Oxford University Press).

6. This information has been taken from the Company Law syllabuses and resources of the Schools of Law of the British universities of London, Bristol, Southampton, Reading, Leicester and Gloucestershire and from the Australian RMIT university, from the Comparative Company Law syllabuses of the universities of Auckland (New Zealand) and Wake Forest (North Carolina), from the Law of Business Organisations syllabus of the University of London International Programmes, from the Evolution of Corporate Law and Finance syllabus of the university of Illinois (US), from the Corporate Law and Corporation Law programs and Advanced Corporate Law Seminars of the American universities of Harvard, Chicago and New York or from the Business Associations syllabus of the university of Victoria (Canada).

7. In this respect, see also Arnold, Jane \& Dornyei, Zoltan 2015: The Principled Communicative Approach. London: Helbling Languages GmbH.; Richards, Jack C \& Rodgers, Theodore S. 2014: Approaches and Methods in Language Teaching. Cambridge: Cambridge University Press; Hughes, John 2014: ETpedia: 1000 Ideas for English Language Teachers. Brighton: Pavilion Publishing; Terrell, T. D. 1991: "The role of grammar instruction in a communicative approach". Modern Language Journal, 75(1), 52-63; Hedge, Tricia 2000: Teaching and Learning in the Language Classroom. Oxford: Oxford University Press; Oxford, R. L., et al. 1989: "Language learning strategies, the communicative approach, and their classroom implications". Foreign Language Annals, 22(1), 29-39; Pica, T. P. 1988: "Communicative language teaching: An aid to second language acquisition? Some insights from classroom research". English Quarterly, 21(2), 70-80; Clark, J. L. 1987: "Classroom assessment in a communicative approach". British Journal of Language Teaching, 25(1), 9-19; Morrow, K., \& Schocker, M. 1987: "Using texts in a communicative approach". ELT Journal, 41(4), 248-56; Rosenthal, A. S., \& Sloane, R. A. 1987: "A communicative approach to foreign language instruction: The UMBC project". Foreign Language Annals, 20(3), 245-53; Dolle, D., \& Willems, G. M. 1984: "The communicative approach to foreign language teaching: The teacher's case". European Journal of Teacher Education, 7(2), 145-54.

However, this approach was also criticised, as can be seen in Swan, M. 1985: "A critical look at the communicative approach (1)". ELT Journal, 39(1), 2-12; Swan, M. 1985: "A critical look at the communicative approach (2)". ELT Journal, 39(2), 76-87.

8. See also Fuertes Olivera, Pedro A. 2004: "English for Contract and Company law", 2nd ed. Marcella Chartrand, Catherine Millar and Edward Wiltshire. London, Published by Sweet \& Maxwell, 2003. 208 + vii pages. ISBN: 042179870 X”. IBÉRICA, 8: 157-59. 
9. In http://www.cambridge.org/es/elt/catalogue/subject/project/item2424317/ Introduction-to-International-Legal-English/?site_locale=es_ES\&currentSubjectID= 2561588 .

10. In http://www.cambridge.org/es/elt/catalogue/subject/project/item2424317/ Introduction-to-International-Legal-English/?site_locale=es_ES\&currentSubjectID= 2561588 .

11. In http://www.sweetandmaxwell.co.uk/Catalogue/ProductDetails.aspx?recordid $=3908 \&$ searchorigin $=$ english $\&$ productid $=234200$.

12. In http://www.sweetandmaxwell.co.uk/Catalogue/ProductDetails.aspx?recordid $=3908 \&$ searchorigin $=$ english $\&$ productid $=234200$ ).

13. Enrique Alcaraz Varó's El inglés jurídico. Textos y Documentos (2007), a classic in the field for Spanish students and practitioners, and also an excellent tool for those who approach legal English for the first time, includes the analysis of a few texts on the matter, which could be useful. Enrique Alcaraz Varó, Miguel Ángel Campos Pardillos and Cynthia Miguelez's El inglés jurídico norteamericano also includes a section on "Derecho societario" (Company Law).

14. For example, one of the exercises students are required to do consists in viewing a film, of my choice, about legal matters on their own and later, arranged in groups, write a follow-up and stage it in English, in the moot-room. The performance is assessed.

\section{References}

Alcaraz Varó, Enrique (2007 [1994]): El inglés jurídico. Textos y Documentos. Barcelona: Ariel Derecho.

Alcaraz Varó, Enrique, Miguel Ángel Campos Pardillos and Cynthia Miguélez (2013 [2001]): El Inglés Jurídico Norteamericano. Barcelona: Ariel.

Arnold, Jane and Zoltan Dornyei (2015): The Principled Communicative Approach. London: Helbling Languages GmbH.

Boyle, Anthony J. and Richard Sykes (eds.) (2004): Gore-Browne on Companies. Bristol: Jordans, Ltd.

Bradley, Caroline and Judith Freedman (1990): “Changing Company Law?" J. H. Farrar, N. Furey, B. Hannigan, Farrar's Company Law, $2^{\text {nd }}$ ed., London: Butterworths, 1988. In Modern Law Review 53: 397-405.

Brown, Gillian D. and Sally Rice (2007): Professional English in Use: Law. Cambridge: Cambridge University Press.

Campos Pardillos, Miguel Ángel (2007): "El lenguaje de las ciencias jurídicas: Nuevos retos y nuevas visiones". In E. Alcaraz, J. Mateo \& F. Yus, eds., Las lenguas profesionales y académicas. Barcelona: Ariel / IULMA, 155-165.

Chartrand, Marcella, Catherine Millar and Edward Wiltshire (2009 [1997]): English for Contract and Company Law. Andover: Sweet \& Maxwell.

Cheffins, Brian R. (1999): "Using theory to study law: A Company Law perspective". The Cambridge Law Journal 58(1): 197-221.

Clark, John L. (1987): "Classroom assessment in a communicative approach". British Journal of Language Teaching 25(1), 9-19.

Copp, Stephen F. (2005): "Company Law and Cod-liver Oil". Bournemouth University Learning and Teaching Conference, Enhancing Graduate Employability: 31-37. 
Day, Jeremy, Amy Krois-Lindner and Matt Firth (2008): Introduction to International Legal English. Cambridge: Cambridge University Press.

Davies, Paul and Sarah Worthington (2012 [1969]): Gower \& Davies: Principles of Modern Company Law. London: Sweet \& Maxwell.

Dignam, Alan and John Lowry (2014 [2006]): Company Law. Oxford: Oxford University Press.

Dolle, Dora amd Gerard M. Willems (1984): "The communicative approach to foreign language teaching: The teacher's case”. European Journal of Teacher Education 7(2): 14554.

Dudley-Evans, Tony and Maggie Jo St John (1998): Developments in English for specific purposes: a multi-disciplinary approach. Cambridge: Cambridge University Press.

Duhaime's Law Dictionary. http://www.duhaime.org/LegalDictionary/B/ BlackLetterLaw.aspx (Retrieved on 2015/12/179).

"European Union Company Law Directives". In P. Davies and S. Worthington (2012 [1969]): 129-138. Updates at http://ec.europa.eu/internal_market/company/index_en.htm.

French, Derek, Stephen Mayson and Christopher Ryan (2015 [1983]): Mayson, French and Ryan on Company Law. Oxford: University Press.

Goulding, Simon (1998): Principles of Company Law. London: Routledge Cavendish.

Hannigan, Brenda (2013): Company Law. Oxford: Oxford University Press.

Hedge, Tricia (2000): Teaching and Learning in the Language Classroom. Oxford: Oxford University Press.

Hicks, Andrew (1994): "Introducing Modern Company Law; the life of a company". The Law Teacher 28 (2): 138-143.

Hicks, Andrew and S.H. Goo (2008 [1994]): Cases \& Materials on Company Law. Oxford: Oxford University Press.

Hughes, John (2014): ETpedia: 1000 Ideas for English Language Teachers. Brighton: Pavilion Publishing.

Hutchinson, Tom and Alan Waters (1987): English for specific purposes: A learning-centred approach. Cambridge: Cambridge University Press.

Hymes, Dell H. (1972): "On communicative competence". In J.B. Pride and J. Holmes, eds., Sociolinguistics. Harmondsworth: Penguin, 269-293.

Kershaw, David (2009): Company Law in Context, Text and Materials. Oxford: Oxford University Press.

Kraakman, Reinier, John Armour, Paul Davies, Luca Enriques, Henry Hansmann, Gérard Hertig, Klaus Hopt, Hideki Kanda and Edward Rock (2009): The Anatomy of Corporate Law. Oxford: Oxford University Press.

Krois-Lindner, Amy (2011 [2006]): International Legal English. A Course for Classroom or Self-Study Use. Cambridge: Cambridge University Press.

Mackenzie, Ian (2007 [2006]): Professional English in Use: Finance. Cambridge: Cambridge University Press.

McKay, William R. and Helen E. Charlton (2011 [2005]): Legal English. How to Understand and Master the Language of the Law. Harlow: Pearson / Longman.

Morrow, Keith and Marita Schocker (1987): "Using texts in a communicative approach". ELT Journal 41(4): 248-56.

Oswald, Marion (2010): "The story of a Phoenix, a Chef and some Raptors: Piecing together the Company Law Jigsaw". Association of Law teachers $45^{\text {th }}$ Annual Conference. Legal 
Education: Making a Difference. http://www.lawteacher.ac.uk/events/cambridgeconference-papers/ (Retrieved on 20/08/2005), 1-11.

Oxford, Rebecca. L. Roberta Z. Lavine and David Crookall (1989): "Language learning strategies, the communicative approach, and their classroom implications". Foreign Language Annals 22(1): 29-39.

Pennington, Robert (2001): Pennington's Company Law. Kiddlinton: Butterworths.

Pica, Teresa P. (1988): "Communicative language teaching: An aid to second language acquisition? Some insights from classroom research". English Quarterly 21(2): 70-80.

Richards, Jack C. and Theodore S. Rodgers (2014 [1986]): Approaches and Methods in Language Teaching. Cambridge: Cambridge University Press.

Rosenthal, Alan S. and Robert A. Sloane (1987): "A communicative approach to foreign language instruction: The UMBC project". Foreign Language Annals 20(3): 245-53.

Schmithoff, Clive M. \& James H. Thompson (eds,) (1992 [1959]): Palmer's Company Law. London: Stevens.

Sealy, Len and Sarah Worthington (2013 [2007]): Cases and Materials on Company Law. Oxford: Oxford University Press.

Snaith, Ian (1990): "Company law on degree courses: survey report". The Company Lawyer 11(9): 177-183.

Swan, Michael (1985): "A critical look at the communicative approach (1)". ELT Journal 39(1): 2-12.

Swan, Michael (1985): "A critical look at the communicative approach (2)". ELT Journal 39(2): 76-87.

Terrell, Tracy D. (1991): "The role of grammar instruction in a communicative approach". Modern Language Journal 75(1): 52-63.

Topham, Alfred Frank (1978): Principles of Company Law. London: Butterworth \& Co Publishers Ltd.

WebFinance, Inc. (2015): Business Dictionary. http://www.businessdictionary.com/ definition/company-law.html (Retrieved on 20/03/2015). 